This item was submitted to Loughborough's Research Repository by the author.

Items in Figshare are protected by copyright, with all rights reserved, unless otherwise indicated.

\title{
Sport and the politics of national identity in the two Chinas
}

PLEASE CITE THE PUBLISHED VERSION

https://www.routledge.com/Sport-and-National-Identities-Globalization-and-Conflict/Dolan-

Connolly/p/book/9781138697768

\section{PUBLISHER}

Routledge $@$ the author

VERSION

AM (Accepted Manuscript)

\section{PUBLISHER STATEMENT}

This work is made available according to the conditions of the Creative Commons Attribution-NonCommercialNoDerivatives 4.0 International (CC BY-NC-ND 4.0) licence. Full details of this licence are available at: https://creativecommons.org/licenses/by-nc-nd/4.0/

\section{LICENCE}

CC BY-NC-ND 4.0

\section{REPOSITORY RECORD}

Bairner, Alan. 2019. "Sport and the Politics of National Identity in the Two Chinas". figshare. https://hdl.handle.net/2134/26953. 


\section{Sport and the politics of national identity in the Two Chinas}

\section{Alan Bairner (Loughborough University)}

\section{Introduction}

The existence of a close relationship between sport and nationalism is widely accepted. This relationship manifests itself in the enduring popularity of international competitions, events and contests, in the myriad ways in which politicians and politically motivated groups have sought to harness sport to national causes and also in the concept of national sports (Bairner, 2009). Nevertheless, questions are increasingly being asked about the future of this relationship between sport and nationalism as well as about the fate of the nation itself (Maguire, 1999; Bairner, 2008, Miller et al, 2001).

Much of the literature on the relationship between sport and nationhood has been concerned with the ways in which nation states seek to promote themselves, or simply carry out their economic and diplomatic business, using sport as a useful and highly visible medium. For example, during the Cold War, it was apparent that the Soviet Union and most, if not all, of its east European neighbours used sport in general and especially the Olympic Games to advertise their particular brand of communism (Riordan, 1978; Dennis and Grix, 2012). Moreover, international rivalry was not only acted out on the athletics track or on the high beam but also impacted on the wider context of events such as the Olympics with the United States seeking to lead a boycott of the Moscow Games in 1980 and the Soviet Union and its allies responding in kind when the Olympics moved to Los Angeles in 1984. Related to this is the fact that nation states also put considerable efforts into acquiring the right to host major events, which are then turned into spectacular exercises in self-promotion by the successful 
bidders. There can be little doubt that most national leaders in the modern world are highly conscious of the role that sport can play in boosting confidence, facilitating closer diplomatic links and securing markers of esteem.

Sport is also commonly implicated in the cultural politics of submerged nations and nationalisms. Thus within the United Kingdom, for example, sport is a hugely significant vehicle for the reproduction of distinctive national identities (Scottish, Welsh, (Northern) Irish and, increasingly, English, within the context of a multi-national nation state. Similar observations can be made about Spain, Canada and other nation states where one finds varying levels of contestation between official nationalities and unofficial national identities.

For most sportsmen and women, even in an era when money is a major incentive for achieving sporting success, representing the nation remains important. However, it is quite conceivable that in the course of their sporting careers, they might represent more than one nation with neither ethnic origin nor even well-established civic connections being necessary for a move from one to another. Yet, even in an era of large-scale global migration, for the overwhelming majority of athletes engaged in international sport, the matter of which country to represent remains relatively clear-cut. For fans, things are arguably even simpler. In the modern era, following one’s 'proxy warriors' into international competition is one of the easiest and most passionate ways of underlining one’s sense of national identity, one’s nationality or both (Hoberman, 1984). Needless to say, not everyone wishes to celebrate their national affiliation in this way, in most instances for the simple reason that they are not interested in sport, the nation or the relationship between the two. But just as for most active participants, for most sports fans the choice is relatively straightforward. This is not to deny 
of course that in certain circumstances athletes and fans alike may well understand their nations in different ways.

There are some grounds for believing that the link between nationalism and sports is becoming weaker and that the very existence of international competition is threatened by the twin forces of globalisation and consumer capitalism. For the time being, however, even though it manifests itself in a wide variety of ways, the relationship between sports and nations remains strong, nowhere more so than in East Asia, where examples are to be found of sport's role in the quest for prestige, the quest for recognition or a combination of the two.

Although analyses of international relations in East Asia often focus on rivalries and tensions involving China, Japan and the two Koreas (Sun, 2013; Lee and Maguire, 2011; Ok and Park, 2015; Bridges, 2015), in terms of the relationship between sport and national identity politics the issue of the Two Chinas has been and remains particularly problematic. The Republic of China (Taiwan) and the People’s Republic of China (PRC) have a difficult relationship which can be traced back over centuries depending upon what one considers to be the key contributory factors. Nevertheless, for those whose interest in global politics is largely bound up with a focus on sport, there may well be little or no recognition of the terms Republic of China (ROC) or even Taiwan. On the other hand, seasoned fans of golf, baseball, tennis and the Olympic Games are almost certainly aware of the name Chinese Taipei. This chapter examines the reasons why the name of Taiwan seldom appears as a named polity in the world of international sport despite the fact that much of the island nation's population regard this as the most appropriate name for their country. The chapter identifies China's role in this 
situation together with Taiwan's response and also discusses the engagement with sport in relation to the politics of national identity of the two Chinas

\section{China, its neighbours and sport}

It is relatively easy to trace the most recent manifestation of tensions between China and Taiwan to the end of the Chinese civil war which resulted in the triumph of the Communist Party over the nationalist Kuomintang (KMT) which at that point then decamped to Taiwan, formerly colonised by the Japanese and subject over the years to numerous other foreign influences. According to Roy (2003: 1), ‘Taiwan’s present circumstances are peculiar and intriguing' - scarcely surprising given the island's complex history. By extension, it should come as no surprise that a country with such a unique past has also experienced a troubled history in terms of sport development, the construction of national identity and the relationship between the two. The main reason for this is the PRC's consistent refusal to allow Twain to be recognised as an independent sovereign state. According to an editorial in a Taiwan English-language newspaper, ‘Taiwan’s isolation from the formal world community despite our substantive status as a democratic independent state due to opposition by the authoritarian People's Republic of China (PRC) has been a long-standing and deeply felt injustice to our 23 million people’ (Taiwan Times, 30 September, 2009).

In reality, one element of the world community from which Taiwan is certainly not formally excluded is international sport. However, the country’s relationship with the Olympic movement and with international sport more generally, has for many years been in circumstances chosen by others - specifically the International Olympic Committee (IOC) 
and the PRC - rather than by the people of Taiwan themselves. For that reason, the Olympics have long been recognised as political by the Taiwanese. Indeed, all mega events have been politicised as a consequence of Chinese attempts to prevent Taiwan from being a host country. For example, Marcus Chu (2014) has argued that, although, from the 1980s, China has not obstructed Taiwan from joining international sports organizations or participating in international sports events, the Chinese authorities have regularly used competition to host major sports events with the aim of defending its 'One China' policy.

The PRC itself has of course become increasingly involved in international sport, and especially the Olympic movement, its primary goal primary being best understood in terms of ‘soft power’ (Nye, 2014). This has been exemplified most dramatically by Beijing winning the right to host both the summer and winter Olympics. However, in addition to strengthening China’s standing in the world of nation states, another significant objective of the Beijing Games for the PRC leadership was to promote the cause of Chinese nationalism (Price and Dayan, 2008)). One element of that overall ambition was to strengthen cohesion within a multi-national and ethnically diverse country and also to make the Special Administrative Regions (SARs) i.e. Hong Kong and Macao identify more strongly with mainland China than perhaps had been the case in the past, particularly in the case of the former (Ho, 2012; Ho and Bridges, 2014).

It is worth remembering, for example, that Hong Kong, the former British colony, was selected as the venue for the equestrian events at the Beijing Games (Ho. 2012). Ho (2012: 33-34) concludes her analysis of the impact of this event on attitudes in Hong Kong by commenting on 'the initial excitement about the opportunity to co-host the equestrian event, 
the exaggerated popularization of equestrianism in a small city like Hong Kong and the active promotion of Chinese nationalism to achieve a sense of internationality by promoting the Olympic spirit'. Here the objective was to link sport to China's 'One Country, Two Systems' policy rather than the 'One China’ approach which has bedevilled relations with Taiwan. More in keeping with the latter was the presence of members of Taiwan's indigenous tribes alongside representatives of mainland China's minority groups at the Opening Ceremony of the 2008 Games. However, China’s strategy was recognised by leaders of the Taiwan delegation who objected to any reference to the aboriginal performers as being members of a 'minority', making it very clear that they were citizens of the Republic of China i.e. Taiwan and not simply members of another Chinese minority (Loa, 2008).

In addition to this relatively covert operation, an overt attempt was made to bring Taiwan further into the PRC's ambit by arguing that the use of the name 'Chinese Taipei', ironically insisted on in the past by China to make Taiwan’s Olympic participation acceptable, should be replaced for the Beijing Olympics with 'China Taipei’ (Bairner and Hwang, 2011). As Hong Kong was referred to for Olympic purposes as ‘China Hong Kong’, such a name change would have created the false impression that Taiwan is also a SAR. This demand was successfully challenged by the Chinese Taipei Olympic Committee (CTOC). The entire episode, however, was by no means a simple matter of sports diplomacy. The issues involved go right to the heart of the problem of contested identity in Taiwan. It is significant that, although the Beijing Games had the potential to enhance the pride that Taiwan’s Han Chinese majority has in its Chinese ancestry and culture, the attempt to translate this pride into closer political identification with mainland China has been, for various reasons, largely unsuccessful as manifest, for example, in the electoral success achieved by the proindependence Democratic Progressive Party (DPP) in 2016. For further understanding of the 
development of sporting relations between the PRC and Taiwan, however, let us first look back at the origins of this particular issue.

\section{The emergence and unfolding of the 'Two Chinas' issue}

Taiwan itself is a society divided along the lines of ethnicity and national identity. There are four major groups on the island. The earliest recorded human inhabitants of what we now know as Taiwan consisted of the ancestors of today's indigenous or aboriginal peoples who constitute around $2 \%$ of the island's current population. Officially there are fourteen aboriginal ethnic groups registered in Taiwan: Ami, Atayal, Bunun, Kavalan, Paiwan, Puyuma, Rukai, Saisiyat, Tao, Thao, Tsou, Truku, Sakizaya, and Seediq. Their languages are part of the proto-Austronesian linguistic family to which Malaysian and Hawaiian also belong. The Han Chinese group (consisting of Holos and Hakkas) who moved from southern mainland China to Taiwan from the end of the seventeenth century comprises $85 \%$ of the population (Holos 70\% and Hakkas 15\%). They are often referred to as internal province people and are generally able to speak Taiwanese and/or Hakka as well as Mandarin Chinese. Those who escaped to Taiwan after 1949 and the triumph of the communist party in mainland China and their descendants constitute around $13 \%$ of the overall population. They are referred to as external province people and are relatively seldom able to speak Taiwanese or Hakka.

Although Japanese colonial rule which was introduced in 1895 met with some initial resistance, over time there emerged widespread acquiescence amongst the Holo, Hakka and 
aboriginal populations. Indeed, there remains a large measure of admiration for what Japanese colonialism bequeathed to Taiwan in marked contrast to attitudes in both Korea and mainland China to their former imperial overlords (Ok and Park, 2015). Rule by the incoming KMT was never accepted to the same extent. Indeed, the new rulers were only able to maintain order and stability through an extended period of martial law which led to the deaths and imprisonment of members of the opposition movement. The contemporary political situation is paradoxical given that the PRC claims sovereignty over Taiwan - hence the concept of 'One China' - while the KMT also seeks closer ties with mainland China although not full incorporation while the communists remain in power. Meanwhile a range of opposition voices led by the DPP seek full independence for Taiwan and recognition of its status at the United Nations.

In relation to sport, the PRC was ostracized by the Olympic movement from 1949. After an absence of over thirty years, however, it was restored to the Olympic family and its athletes competed at the Los Angeles Games in 1984, the first occasion when the PRC and Taiwan took part at the same Olympics. In 1949, some Chinese Olympic Committee members had fled with the KMT to Taiwan and the ROC government maintained contact with the IOC, claiming jurisdiction over Olympic affairs in both mainland China and Taiwan. This claim was subsequently challenged by the PRC, since the Chinese National Amateur Athletic Federation (CNAAF) was still based in Nanjing (in mainland China). Subsequently, the CNAAF was reorganized and renamed in October 1949 as the All-China Athletic Federation (ACAF) which claimed leadership over all Chinese Olympic activities. These competing claims for jurisdiction by the PRC and Taiwan inevitably led to conflict. 
The PRC had no contact with the IOC until February 1952 when the ACAF sent a message expressing its wish to participate in the Helsinki Games, placing the IOC in a difficult position, since Taiwan also intended to take part. According to IOC rules, only one national committee was permitted to represent a country and there were differences of opinion among IOC members as to which Chinese committee should be recognised. Neither the PRC nor Taiwan was willing to negotiate or to form a single team. As a result, the IOC adopted a proposal permitting both committees to participate in those events in which they had been recognised by the relevant international governing bodies. Taiwan was disappointed by the IOC resolution and withdrew from the 1952 Helsinki Olympics in protest.

Two years later, the PRC was formally recognised by the IOC as the Olympic Committee of the Chinese Republic (later changed to the Olympic Committee of Democratic China) (Olympic Review, No. 66-67, May-June, 1973). At the same time, Taiwan was recognised in the name of the Chinese Olympic Committee. In this way, the Olympic movement had reached a 'two Chinas' resolution and both the PRC and Taiwan were invited to take part at the 1956 Melbourne Olympics. On this occasion, however, the PRC withdrew in protest at Taiwan’s participation and demanded its expulsion from the IOC. In response, Avery Brundage, the then President of the IOC, wrote to Beijing on 8 January, 1958:

Everyone knows that there is a separate government in Taiwan, which is recognized internationally, and specifically by the United Nations consisting of the governments of the world. Your government is not recognized by the United Nations (Olympic Review, No. 145, November 1979: 628).

Disappointed by this, the PRC withdrew its membership of the IOC and of nine other international sporting organizations in 1958 and, as a consequence, during the 1960s, Taiwan was able to claim to represent all of China in international sport. However, in October 1971, after the PRC had been admitted to the United Nations, creating a major political setback for 
the KMT, the ROC (Taiwan) was expelled, thereby aiding the PRC's efforts to participate in other international organizations and, specifically, the Olympic movement. The PRC applied to rejoin the IOC in April, 1975 and was granted admission in 1979. How precisely was Taiwan affected by these developments?

Prior to the 1976 Olympic Games to be held in Montreal, the PRC requested Canada to unconditionally bar the Taiwanese delegation from Montreal. Instead, the Canadian government asked Taiwanese athletes to compete without any mention of the word China or use of the term 'Republic of China'. The IOC considered the Canadian action to be a breach of a promise made in 1970 when Montréal was chosen as the host city (Espy, 1979) and, to avoid further confrontation with the Canadian government, submitted a plan that Taiwan should be allowed to participate as 'Taiwan-ROC' with a flag bearing the Olympic rings. This solution attracted opposition from both the PRC and Taiwan with the former indicating that 'ROC' was only an abbreviation of the title Republic of China and, therefore, to adopt it would be to officially acknowledge the 'Two Chinas'. For its part, Taiwan insisted on competing under its own flag using the name, 'Republic of China'. Thus, from the moment of its admission into the Olympic family, the PRC maintained that there was one China not two or even one China and one Taiwan and refused to accept any conditions under which Taiwan could be recognised. In June 1979, the IOC executive committee meeting in Puerto Rico confirmed China’s Olympic Committee’s title as the ‘Chinese Olympic Committee’. It also recommended that Taiwan should stay in the IOC as the 'CTOC' with a different national anthem and flag (Bairner and Hwang, 2011). 
Taiwan was again disappointed with the IOC decision to the extent that Taipei’s Olympic Committee and Henry Hsu, an IOC member from Taiwan, filed lawsuits at the Lausanne Civil District Court against the subsequent Nagoya resolution, which confirmed the decision taken in Puerto Rico, claiming that it violated IOC rules. This claim was rejected by the court. In his ruling, Judge Pierre Bucher said that it seemed obvious that Taipei’s Olympic Committee had no right to bring a suit against the IOC (Daily Report, 17 January, 1980: A2). However, the new IOC President Juan Antonio Samaranch sent a letter to Hsu, dated 4 December, 1980, guaranteeing that Taipei’s Olympic Committee would get the same treatment as any other national committee if Taiwan accepted the conditions of the Nagoya resolution (Chinese Taipei Olympic Committee, 1981). Consequently, the Taipei Olympic Committee agreed to change its name to the 'Chinese Taipei Olympic Committee’ and to adopt a new flag and emblem. According to the agreement, the Chinese Taipei Olympic Committee would, thus, be entitled to take part in future Olympic Games and other activities sponsored by the IOC like every other National Olympic Committee, with the same status and rights (Olympic Review, No. 162, April, 1981). At least temporarily, the question of Chinese representation was settled. For the PRC, there were no 'two Chinas' or one China and one Taiwan. There was one China with Taiwan, to all intents and purposes, being subsumed or subordinate - implicitly at least according to the naming of the two Olympic committees. This outcome helped to facilitate communication between China and Taiwan through sport and was even seen by some as conducive to a reunification process. For Taiwan, there was no option but to accept the resolution if it wished to stay in the Olympic movement; for the IOC, one of its biggest problems of the previous twenty years had been resolved. 
By the time of the 2004 Olympics in Athens, the National Council on Physical Fitness and Sport announced that the Chinese Taipei Olympic team would consist of 85 competitors across 12 events. Coverage of the Games would be provided by digital broadcast stations with the IOC granting broadcasting rights to Taiwan Television Enterprise Limited, China Television Company, Chinese Television Systems and Formosa Television. The CTOC praised the IOC for promoting cooperation between the four stations not least because the mission of the CTOC remains that of promoting the Olympic movement in Taiwan. This should not be taken as incontrovertible evidence, however, that problems associated with acts of naming were at an end.

\section{Representing Taiwan}

Although it is undeniable that successive Taiwan governments have emphasised the significance of sport, it is important to understand what this has meant in practice. China's traditional values, which have been as influential in Taiwan, if not more so, as they have been in mainland China, consciously distinguished wen and wu, meaning the 'civil' (or cultural attainment) and the 'martial' (or physical valour) respectively. Overall, wen refers to the use of the mind, while wu concentrates on the body and refers to physical strength. Because of the civil service examination system which was put into effect during the Sui dynasty in China, the idea that 'everything is low-class work except academic study' has permeated Chinese society and indeed east Asian society more generally.

The ancient Chinese philosopher and follower of Confucius, Mencius, developed this idea even further by saying: 
Great men (gentlemen) have their proper business, and little men (petty men) have their proper business... Hence there is the saying 'some labor with their minds and some labor with their strength. Those who labor with their minds govern others; those who labor with their strength are governed by others. Those who are governed by others support them; those who govern others are supported by them' (Laoxin zhe zhiren, laoli zhe zhiyuren). This is a principle universally recognized (Mencius, 1960: 124).

If we remind ourselves of the ethnic divisions within Taiwan's population, we find what might be described as “over-representation” of aborigines in baseball, Taiwan's national sport, a legacy of the Japanese colonial period. Whilst aboriginal people account for only $2 \%$ of the overall population, in the $18^{\text {th }}$ season of the Taiwan Professional Baseball League, there were 76 aboriginal players, nearly $41 \%$ of the total number of players. In the $22^{\text {nd }}$ Asian Baseball Championship in 2003, the Taiwan team which were runners-up and gained automatic entry into the Athens Olympics of 2004, was 45\% aboriginal in composition. Although Taiwan aborigines and baseball have become synonymous, the contingent impact on their identity is relatively rarely discussed either in national discourses or in sport studies. Yet this is an important subject not least because sport can be such a significant factor in the production and reproduction of national identity and, in the case of Taiwan, this has been most clearly demonstrated as a consequence of the achievements of athletes who belong to a relatively small, indigenous section of the overall population.

In many ways, the story of aboriginal players in Taiwanese baseball is familiar but no less depressing for that. It is a tale of sport being used by successive ruling elites in order to incorporate indigenous peoples into a collective national project. Subaltern groups are offered the opportunity through sport to progress to professional careers and, in some cases, to 
national acclaim. Many others fail to make the grade and, in the meantime, stereotyping coalesces around the idea that whilst aboriginal peoples may have innate physical prowess, their mental capacities are limited. As a consequence, other careers are denied to those who do not make it in sport not least with the emergence of schools primarily concerned with athletic talent spotting ( $\mathrm{Yu}$ and Bairner, 2010).

Thus, although baseball has been central to attempts to use sport for political purposes in Taiwan has been problematized by the disproportionate role played by aboriginal and the ramifications which follow from this. Furthermore, for serious competition in East Asia Taiwan has traditionally looked to Japan and to a lesser extent South Korea given that baseball has been relatively insignificant in Chinese sporting culture. However, it did make its mark on China-Taiwan relations during the Beijing Olympics with the Chinese Taipei team's losses in Beijing at the hands of their Chinese opponents representing one of the lowest pints in Taiwan’s sporting history.

On 15 August, 2008, after twelve innings, Taiwan's national baseball team lost to the PRC team for the first time ever. This was a massive shock for most Taiwanese. The following day, Taiwan’s media was calling it 'the darkest day of Taiwan’s baseball history' (Huang, 2008). According to Tseng et al (2008), Taiwanese baseball fans were so upset that some requested that the national baseball team 'swim back' to Taiwan as a form of punishment. Some Taiwanese saw 15 August as a day of national humiliation 
In this regard, it is also useful to understand the ways in which Taiwanese female athletes have been represented in media discourses of sport and Taiwanese nationalism and the symbolic roles they have been assigned (Chiang et al, 2015). Born in 1944, Chi Cheng is the most famous woman track and field athlete in Taiwanese history. She won a bronze medal in the 80 metres hurdles at the 1968 Summer Olympics. The webpage of the National Museum of Taiwan History’s 'Women of Taiwan' section describes Chi Cheng as follows:

Who achieved such a great success? The American media called her 'the fastest woman in the world'; the German press praised her as 'the Oriental Flying Antelope'; the Greek media called her 'Yellow Lighting'. She is the well-known 'Flying Antelope' - Chi Cheng. Chi Cheng was the 'glory of Taiwan' in the 1970s.

As a former 'glory of Taiwan', Chi Cheng became a political figure after retirement. She was elected as an independent legislator, serving from 1980 to 1989. In 2009, she was appointed as a National Policy Adviser by President Ma Ying-jeou. Chi Cheng became not only an ambassador for sport in Taiwan, but also an important media resource when Taiwan faces international sport politics difficulties. By 2001, she and other athletes were rallying support for a cross-strait, long-distance run in support of Beijing's bid to host the Olympic Games. At a later stage, when, for political reasons, the Olympic torch was unable to pass through Taiwan, Chi Cheng stated straightforwardly that this was a disappointment (Bairner and Hwang, 2010). Nonetheless, prior to the Games themselves, Chi Cheng herself suggested boycotting the opening ceremony of the Beijing Olympics expressing concern over President Ma's acceptance of China's arrangement for the Taiwanese sports team's order of appearance in the Olympic procession (Su, 2008). 
Between 1960 and 2008, whether for 'the Republic of China Olympic Committee' and 'the Chinese Olympic Committee, Taipei' or the 'Chinese Taipei Olympic Committee', Taiwan athletes won nineteen medals at the summer Olympics. Ten of these were won by female athletes. At the 2004 Olympics, female Taekwondo player Chen Shih-hsin won the first Olympic gold medal in Taiwanese history, thereby becoming the 'glory of Taiwan' for that particular year.

After the embarrassing failure of the national baseball team at the Beijing Olympics, the dominant discourse linking male athletes to nationalism was transferred to their female colleagues. Women athletes who had initially been trapped in a marginal position within media representation became the focus of coverage and the source of national hope for Taiwan. Many female athletes achieved good performances in the summer Olympics. Thus, when Taiwan's male athletes failed in the Olympics hosted by the country’s biggest rival, these women athletes seized the moment and thereby boosted their own social status. The extent of this sort of empowerment is, of course, minimal. There was nonetheless an opportunity for Taiwanese female athletes to experience a degree of upward mobility (Chiang et al., 2015). Whether such progress can be maintained is another matter although the election of a female President is further evidence of change.

\section{The 2008 Beijing Olympic Games}

In seeking to host a range of sport mega events, the Chinese government demonstrated its recognition of the value of 'soft power' and the extent it which it could enhance China's image and allow for more harmonious interaction with the rest of the world. For example, 
unlike US President Barack Obama, British Prime Minister David Cameron and German Chancellor Angela Merkel who refused to attend the Sochi Winter Olympics opening ceremony on 7 February 2014 because of the Russian government's harsh crackdown on the homosexual community (McDonnell, 2014), Chinese President Xi Jinping had no such reservations (Chu, 2015). But why did Xi attend the widely boycotted event at the Russian seaside resort? This article argues that the Sochi trip aimed at (1) displaying Xi’s personal charisma, (2) consolidating China’s relations with Russia, (3) promoting China’s determination to secure world peace, and (4) improving Beijing's odds to win the 2022 Winter Olympics bidding contest. All of this underlines that the Games were to be used as a means to support the realization of Xi's ambitious 'China Dream' (Chu, 2015). But, if that 'Dream' was also to include the constitutional incorporation of Taiwan, the difficulty of achieving that particular objective was underestimated even though events in the lead-up to the Beijing Olympics had given notice of the obstacles that would have to be overcome.

The Olympic Torch is intended to symbolize peace, unity, progress, mutual respect and accommodation. The Chinese regime used it (and their bid to host the 2008 Olympics) to become more closely integrated into the international community, albeit with the potentially ominous implications of pursuing the dream of a harmonious global society. Conversely, the international community thought that the PRC would soften its existing image in order to win the bid to host the Olympics successfully (Tsai, 2007; Yeh, 2004). Despite their proclaimed intent to take the Olympic Torch on a 'Harmonious journey', the Chinese authorities planned a route that raised questions about their political motives in relation to Taiwan (Huang, 2007). The major point of contention was that the route for the Olympic Torch, announced on 26 April, 2007, included Taiwan as part of the domestic leg, indicating Taiwan to be a local 
government under the jurisdiction of the PRC. Additionally, the COC demanded that no national flag, national emblem, or national anthem representing Taiwan should feature on the Torch Relay route, which triggered considerable public resentment in Taiwan. The IOC has historically emphasized a separation of the Games themselves and the policies of individual governments for fear of allowing nation-state politics to impede international sporting exchanges. The fact remains, however, that it has proved very difficult, if not impossible, to protect the Olympics from political undertones (Tsai, 2007; Bairner and Molnar, 2010). Certainly the Torch Relay and its repercussions reinvigorated discussions about Taiwan's identity.

The simple announcement of the logistics of the Olympic Torch Relay touched a raw nerve for many Taiwanese people and inevitably discussions on the related subjects of Taiwan's sovereignty and the significance of the China connection ensued. As revealed in a poll conducted by Taiwan’s Executive Yuan Mainland Affairs Council, over 60\% of the respondents expressed the view that to allow the Torch to pass through Taiwan would diminish the country's claim to sovereignty, and, for that reason, Taiwan should not accept such an arrangement (Tsai, 2007). When asked about the Torch passing through Taiwan during the first stage of the PRC's domestic route, with the stipulation that Taiwan be referred to as 'Taipei, China', nearly $65 \%$ of the respondents said this was unacceptable, and only $16.3 \%$ of the respondents said they would accept Taiwan being the first stop on China's domestic Torch route. As to whether the issue of the Torch passing through Taiwan should be negotiated, those in agreement and those opposed accounted for $42.7 \%$ and $45.7 \%$ respectively. These figures reveal that over a half of the respondents had doubts about Beijing's goodwill, although a substantial minority wanted continued negotiations with the 
PRC authorities in order to allow the Olympic Torch to be taken successfully via Taiwan (Huang, 2007). According to this poll, the concept of Taiwan as a political entity had garnered increasing support following political change in the 1980s and 1990s.

A study that was initiated in January, 2007, involved questionnaire surveys and interviews conducted before and after the Beijing Games (Lee et al, 2010). The initial research method employed a questionnaire survey approach to collect information which helped identify respondents' positions on Taiwanese identity in relation to the circumstances of the 2008 Games. Research participants were identified using the 2007 National Intercollegiate Athletic Games in Taiwan as the sampling frame. These Games included competitions across 11 sports and involved 8199 student athletes from 167 universities in Taiwan. The collegiate athletes were selected because of their status as both athletes and citizens. In addition, their high level of education, together with their knowledge of both sports affairs and the particular relationship between China and Taiwan were also important concerns. A total of 2176 surveys were conducted and 1929 surveys were utilised in the subsequent analysis. The study additionally drew on interviews conducted after the Beijing Games when interviewees’ accounts of their thinking about the Games provided the basis for a deeper analysis of the relationship between Beijing 2008 and national identity issues.

When the respondents were asked, regardless of Beijing's hosting of the 2008 Olympic Games, if they would identify themselves as Taiwanese, both Taiwanese and Chinese or Chinese, $62.41 \%$ selected Taiwanese as their preference; $27.06 \%$ preferred to be identified as both Taiwanese and Chinese and only 8.09\% selected Chinese as their favoured mode of selfidentification. When respondents were subsequently asked to identify themselves in the event 
of Beijing hosting the Olympics successfully, those who claimed they were Chinese constituted more than $12 \%$. The Taiwanese option still came first but its ratio in percentage terms declined from 62.41 to 54.02 . In addition, the percentage of the group identifying as both Chinese and Taiwanese showed a slight increase from $27.06 \%$ to $29.86 \%$ (Lee, et al, 2010)

This, according to these findings, a successful hosting of the 2008 Olympic Games had the potential to affect Taiwanese self-identification, albeit not to a dramatic extent (Lee et al, 2010). The Beijing Games certainly offered China an ideal opportunity with which to undermine confidence in and identification with a distinctive Taiwanese identity. The evidence suggested, however, that it was unlikely that Beijing's hosting of the Olympic Games would be the catalyst for any instant or major transformation of Taiwanese political attitudes (Lee, et al, 2010).

Not surprisingly in a context in which national identity is a highly contested issue, this was by no means the only reading of these events. According to Tzu-hsuan Chen (2010), for example, during the whole negotiation process, the DPP and the administration of Chen Shuibian, Taiwan’s first native-born president, oscillated between different positions. Chen claims that from February, 2006 to February, 2007, a friendly position was taken, this being an extension of the government's softening position towards China. However, when a series of scandals erupted, the administration's approval rating plummeted and, in February 2007, a more hawkish cabinet was appointed. According to Chen (2010), these moves were aimed at redirecting the nation's attention away from Chen Shui-bian’s personal scandals. Inconsistency in terms of attitudes towards the Torch Relay was the inevitable consequence. 
There is certainly no denying former President Chen's attempts to construct a distinctive Taiwanese identity - a 'Taiwan spirit' to which he frequently referred in his major speeches (Chang and Holt, 2009). Like so many of his predecessors who had been empowered to govern Taiwan, he too sought to harness sport for his political ends. In his New Year’s Speech of 2000, 'reflecting the hope of the new millennium...Chen describes a black-andwhite picture of an aboriginal batter of the Red Leaf Little League Team concentrating on the next pitch, while his teammates hold their breath to encourage him. 'Such a beautiful moment', Chen says, 'perfectly captures twentieth century Taiwan and is a memory I will never forget' ( cited in Chang and Holt, 2009: 320). Whilst there was certainly inconsistency on Chen's part in relation to the Beijing Games, and his own personal difficulties were no doubt influential in this regard, it would be wrong to assume that statements of this kind did not reflect a genuine concern for the promotion of a distinctive Taiwanese identity. More problematic perhaps is the question of what exactly should constitute such an identity. Indeed, this may also become an issue that is relevant to the PRC given President Xi's insistence that football should play a leading role in realising the 'China Dream'.

Compared with China's prominent achievement of winning most gold medals with 51 (100 in total) at the 2008 Olympic Games in Beijing, the outcome of its investment in elite football seemed to have brought shame to the then president of the People's Republic China (PRC), Hu Jin-Tao. As a result, after the 2008 Olympics, Hu demanded further actions in order to fulfil China’s sports policy goal of going 'from a major sports country to a world sports power’. Moreover, during an official visit to Germany in 2009, Xi Jin-Ping, the then-vice president and now the current president of the PRC, also expressed the country's 
determination to put considerable effort into China's elite football development. At an official meeting with the president of the Korea Democratic Party in 2011, Xi had highlighted his three World Cup dreams of 'participating in the World Cup', 'hosting the World Cup', and 'being the World Cup champions' In light of China’s leaders' concerns about the future of the country's elite football, the once neglected 'campus football' has attracted increasing attention in the wider society.

\section{Conclusion}

Despite problems associated with the Torch Relay, in general former President Ma's KMT administration succeeded in forging closer links between Taiwan and the PRC. With the election in May 2016 of Taiwan's first female president, the DPPs Tsai Ing-wen, conditions have changed. In addition to seeking to disparage President Tsai’s leadership ability, the Chinese authorities have already taken steps to control the amount of Chinese money that goes into the Taiwan economy

The PRC has also been affected in recent years by events in Hong Kong which have challenged any idea that all Han people can be united around a single political project. Just as Taiwan looks towards Taiwan, so many Taiwanese people look towards developments in Hong Kong. In addition, China contains fifty-five ethnic minorities, most of which have no separatist aims. But problems remain in some parts of the country, most notably among sections of the Uyghur population which do have secessionist ambitions. Sport has done a lot to unify people in the PRC as well as in Taiwan. To that extent, President Xi's inclusion of sport in his aspirational project makes sense. One wonders, however, if the focus on football 
could yet present further challenges to the unitary character of the Chinese state as localism, regionalism and, in particular, city loyalties begin to grow stronger as they do in other countries with a much longer attachment to the game.

I shall conclude this chapter with a story which provides further insight into the often difficult relationship between the PRC and Taiwan and demonstrates that it is not only sport participation that has been affected but also the academic study of sport. In 2014, the annual congress of the International Sociology of Sport Association (ISSA) was held at Peking University in Beijing. A significant number of academics from Taiwan had registered to attend. Not long before the congress was due to take place, the ISSA executive board was alerted to the fact that there was unease on the part of the Chinese hosts that the association's promotional material appeared to indicate that Taiwan is a country. It was suggested that the use of the phrase 'countries and regions', referring to where delegates were from would help. This was unacceptable and equally unacceptable to the Taiwan delegates was a suggestion that the term 'Chinese Taipei', so familiar anyway in the world of sport, could replace 'Taiwan'. In the event, an impasse was reached and the Taiwan delegates decided en masse not to attend. It will be interesting to see how things unfold when the 2017 ISSA congress takes place at the National Taiwan Sport University.

It would be easy to represent relations between the PRC and Taiwan in sport and much else as overwhelmingly unequal. Yet, it might also be argued that Taiwan has the potential to forge a more inclusive national consciousness than can be achieved by the PRC other than by force. What is not open to debate, however, that the relationship between the Two China's 
offers countless insights into the ways in which sport can play an integral part in the politics of national identity.

\section{References}

Bairner, A. (2008) Sports and nationalism in G. H. Herb and D.H. Kaplan (eds.) Nations and Nationalism. A Global Historical Overview, Volume 3 1945-1989. Santa Barbara, California: ABC-CLIO, 991-1004.

Bairner, A. (2009) National Sports and national landscapes: in defence of primordialism, National Identities, 11 (3), 223-39.

Bairner, A. and Hwang, D. J. (2011) Representing Taiwan: international sport, ethnicity and national identity in the Republic of China. International Review for the Sociology of Sport, 46 (3), 231-248.

Bairner, A. and Molnar, G. (eds.) (2010) The Politics of the Olympics - a survey.London: Routledge.

Bridges, B. (2015) Flags, formulas and frustrations: North-South Korean Olympic ‘cooperation’. Asia Pacific Journal of Sport and Social Science, 4 (3), 211-222.

Chang, H.C. and Holt, R. (2009) Taiwan and ROC: A critical analysis of President Chen Shui-bien's construction of Taiwan identity in national speeches. National Identities, 11 (3): 301-330.

Chen, T. H. (2010) The Olympic Torch Relay as a Venue for Political Struggle: the case of Taiwan, East Asian Sport Thoughts, 1, 105-119. 
Chiang, Y., Bairner, A., Hwang, D. J. and Chen, T. H. (2015) Multiple margins: Sport, Gender and Nationalism in Taiwan. Asia Pacific Journal of Sport and Social Science, 4 (1), 19-33.

Chiu, W.C., Hwang, D.J. and Bairner, A. (2104) In the Shadow of National Glory: Taiwan Aboriginal Baseball in the Politics of Identity. International Journal of the History of Sport 31 (3), 347-362.

Chinese Taipei Olympic Committee, 1981.

Chu, M. P. (2014) Shenzhen's bid for the 2011 Summer Universiade and its implications for Taiwan in the international sports community, Asia Pacific Journal of Sport and Social Science, 3 (1): 20-31.

Chu, M. P. (2015) Xi Jinping at Sochi: Leveraging the 2014 Winter Olympics for the China Dream, Asia Pacific Journal of Sport and Social Science, 4 (2): 124-133.

Daily Report, (1980) A2, 17 January.

Corcuff, S, 2002, Introduction: Taiwan, a laboratory of identities. In: Corcuff S (ed.) Memories of the Future. National Identity Issues and the Search for a New Taiwan. Armonk, NY: M.E. Sharpe, xi-xxiv.

Dennis, M. and Grix, J. (2012) Sport Under Communism. Behind the East German 'Miracle'. Houndmills, Basingstoke: Palgrave Macmillan.

Espy, R. (1979) The Politics of the Olympic Games. Berkeley: University of California Press.

Ho, G. (2012) Olympic Culture Shock: when equestrianism gallops to Hong Kong. Asia Pacific Journal of Sport and Social Science, 1 (1), 22-36. 
Ho, G. and Bairner, A. (2013) One Country, Two Systems, Three Flags: Imagining Olympic Nationalism in Hong Kong and Macao. International Review for the Sociology of Sport, 48 (3), 349-365.

Ho, G and Bridges, B. ((2014) Transnational events and impromptu participation: Youth participation in the Olympic Torch Relay in Hong Kong and Macao. Asia Pacific Journal of Sport and Social Science, 3 (3), 277-289.

Hoberman, J. M. (1984) Sport and Political Ideology. Austin: University of Texas Press.

Huang, L. H. (2008) Taiwan's first loss to China, the darkest day of baseball. United Daily News, 16 August.

Lee, J. W. and Maguire, J. (2011) Road to Reunification? : Unitary Korean nationalism in South Korean media coverage of the 2004 Athens Olympic Games. Sociology, 45 (5), 848867.

Lee, P. C., Bairner, A., and Tan, T. C. (2010).Taiwanese Identities and the 2008 Beijing Olympic Games. In A. Bairner and G. Molnar (eds.), The Politics of the Olympics: a survey. London: Routledge.

Loa, L. S. (2008) Aboriginal groups lash out over 'minorities’ moniker. Taipei Times, 8 August. (http://www.taipeitimes.com/News/taiwan/archives/2008/08/08/2003419770). Accessed 30 July 2016.

Maguire, J. (1999) Global Sport. Identities, Societies, Civilizations. Cambridge: Polity Press. McDonnell, J. (2014) Sochi Olympics Cast Spotlight on Russia's LGBT Discrimination. The Diplomat, 15 February, http://thediplomat.com/2014/02/sochi-olympics-cast-spotlight-onrussias-lgbt-discrimination/ (Accessed 7 July 2016) 
Mencius (1960) Annotating and interpreting the Four Books: Mencius. Taipei: Qiming.

Miller, T., Lawrence, G., McKay, J. and Rowe, D. (2001) Globalization and Sport. London: Sage.

Nye, J. S. (2004). Soft power: The means to success in world politics. New York: Public Affairs.

Ok, G. \& Park, K. (2015) The development and significance of anti-Japanism in Korean sport. Asia Pacific Journal of Sport and Social Science, 4 (3), 186-197.

Olympic Review (1973), Nos. 66-67, May-June.

Olympic Review (1979) No. 145, November.

Olympic Review (1981) No. 162, April.

Price, M. E. and Dayan, D. (2008). Owning the Olympics. Narratives of the New China. Ann Arbor, University of Michigan Press.

Riordan, J. (ed.) (1978) Sport Under Communism. Montreal: McGill-Queens University Press.

Roy, D. (2003) Taiwan. A Political History. Ithaca, NY: Cornell University Press.

Su, Y. Y. (2008) Chi Cheng urges boycott of Olympic Games' opening. Taipei Times, 2 August.

Sun, J. (2013) Japan and China as Charm Rivals. Soft Power in Regional Diplomacy. Ann Arbor, University of Michigan Press.

Taiwan Times (2009) 30 September. 
Tsai, M. Y. (2007) The Beijing Olympics Torch’s coming to Taiwan and the Cross-strait Relations, Exchange Magazine. 93: 41-43.

Tseng, Y. C., Tsai, C. Y. and Chen, D. H. (2008) Fans upset, asking lower the national flag to half-mast. United Daily News, 16 August.

Yeh, W. J. (2004). From Athens to Beijing - Analysing the 2008 Beijing Olympics’ cultural philosophy. Unpublished Masters dissertation, National Chengchi University, Taiwan.

Yu, J. W. and Bairner, A. (2010) Schooling Taiwan’s aboriginal baseball players for the nation. Sport, Education and Society, 15 (1), 63-82.

Yu, J.W. and Bairner, A. (2011) The Confucian legacy and its implications for physical education in Taiwan, European Physical Education Review, 17 (2), 219-230 